\title{
A RETROFIT VARIABLE-RATE CONTROL SYSTEM FOR PRESSURIZED SLURRY TANKERS
}

\author{
A. Calcante, M. Brambilla, R. Oberti, C. Bisaglia
}

\begin{abstract}
In the last several decades, livestock effluent management practices and field slurry spreading operations have received increasing attention due to their economic and environmental implications. In this study, a variable-rate control system for pressurized slurry tankers was developed according a retrofit approach (i.e., as a self-standing module that can be adapted and mounted on existing slurry tanker equipment). The system provides farmers with a useful tool for achieving compliance with environmental protection regulations and for developing good practices for livestock and nitrogen management. This system is suitable for new and used pressurized tanker equipment. For field-testing purposes, this system was mounted on a double-axis $10 \mathrm{~m}^{3}$ slurry tanker equipped with a crawling nozzle distribution unit. Field experiments were conducted at two typical forward speeds ( 2 and $3 \mathrm{~km} \mathrm{~h}^{-1}$ ) and three different nitrogen application rates $\left(170,250\right.$, and $\left.340 \mathrm{~kg} \mathrm{ha}^{-1}\right)$.

Based on the experimental results, the system was generally capable of limiting the differences between the nominal and measured application rates to less than 9\%. In addition, the data analysis indicated that the slurry spreading was not significantly affected by the forward speed of the tanker. The uniformity of nitrogen spreading was evaluated according to the UNI EN 13406:2002 standard. The results showed that the transverse field distribution was uniform throughout the working width of the machine and at all tested operating conditions, with maximum deviations that were limited to less than $15 \%$.
\end{abstract}

Keywords. Variable-rate application, Retrofit, Slurry tankers, Precision agriculture, Slurry spreading control.

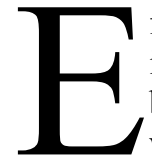
ffluent management has become increasingly important among livestock farming activities because of: $i$ ) the need to valorize a sub-product with a high fertilizing potential, $i i$ ) the high costs associated with spreading operations, and iii) the environmental impacts that could result from inadequate effluent management at the farm level. Due to this issue, the European Commission issued several Directives aimed at protecting the environment while ensuring that farmers could achieve proper production levels (Ruiz-Ramos et al., 2011). In particular, Directive $91 / 676 / \mathrm{EC}$ is currently the main regulation aimed at protecting water from nitrate accumulation due to farming operations. Due to this directive, nitrate vulnerable zones (NVZs) have been set with strict regulations regarding the timing and rates of nitrogen application in these zones. In the NVZs, a specific threshold limits the application rate to $170 \mathrm{~kg} \mathrm{ha}^{-1} \mathrm{y}^{-1}$ for nitrogen. However, this threshold is normally $340 \mathrm{~kg} \mathrm{ha}^{-1} \mathrm{y}^{-1}$ (Mazzetto et al., 2012 b).

Submitted for review in September 2014 as manuscript number MS 10885; approved for publication by the Machinery Systems Community of ASABE in April 2015.

The authors are Aldo Calcante, Assistant Professor, Roberto Oberti, Assistant Professor, Università degli Studi di Milano, Department of Agricultural and Environmental Sciences, Milan, Italy; Massimo Brambilla, Researcher, and Carlo Bisaglia, Senior Researcher, Consiglio per la ricerca in agricoltura e l'analisi dell'economia agraria (CRA), Unità di Ricerca per l'Ingegneria Agraria (CRA-ING), Laboratorio di Treviglio, Treviglio (Bergamo), Italy. Corresponding author: Aldo Calcante, via Celoria 2, IT-20133 Milan, Italy; phone +39-02-50316864; e-mail: aldo.calcante@unimi.it.
From a technology perspective, strict compliance with these limits can be achieved using control systems that use "variable rate technology" (VRT) for spreading fertilizer. These systems are generally classified into four groups that correspond to the following increasing automation levels adapted from Funk and Robert, (2003).

- Automation level 0: This system uses a constant-flow rate distribution and requires devices to deliver a predefined rate of effluent regardless of the operating conditions.

- Automation level 1: During spreading, the flow rate is adjusted depending on the variations of the forward speed of the tanker. A scientific literature review indicates that several researchers have studied this automation level. For example, Safley et al. (1984) developed a variable flow rate distribution system by installing a volumetric lobe pump on a slurry tanker. This system demonstrated the feasibility of modulating the distributed amount of slurry by controlling the pump rotation speed. Scotford et al. (2001) proposed a high-precision distribution system with an in-line sensor for measuring the slurry outflow. Munack et al., (2001) developed a Kalman filter that used an algorithm to process the signal from an electromagnetic flow meter used to measure the slurry outflow. In 2002, England et al. designed a gravimetric system that used load cells to measure the amount of slurry that was distributed in real time. Oh et al. (2004) developed a VRT spreader that was specifically designed for distributing nutrients in paddy fields. 
Balsari et al. (2005) designed a modular VRT fiberglass tanker that was equipped with a volumetric pump. Saeys et al. (2008) proposed a high-precision flow control system for the site-specific application of slurry that used a magneto-rheological sensor. Gioelli et al. (2014) introduced a prototype for variable rate control of slurry distribution based on variable speed lobe pump equipping a non-pressurized tanker.

- Automation level 2: In this system, the slurry application rate is adjusted at each specific site according to a prescribed map (Morris et al., 1999; Schellberg and Lock, 2009). This technology level refers to a precision farming framework that requires interactions with a global positioning system (GPS), a Farm Information System (FIS), and the on-board control system of the slurry tanker.

- Automation level 3: The slurry is distributed to apply nitrogen concentrations that are prescribed for each specific site. This automation level requires specific sensors that can measure the nutrient contents in the slurry. The nutrient contents are measured based on the principle of electrical conductivity (Provolo and Martinez-Suller, 2007) or based on optical signatures, which can be identified using Near Infrared Spectroscopy (NIRS) (Saeys et al., 2005).

This study aimed to develop and test a VRT system under field conditions that was capable of automatically controlling the slurry distribution rate according to a sitespecific prescription map. According to the above classification, the system developed in this research belongs to automation level 2. Nevertheless, the system can be interfaced also with an online nitrogen content sensor (not the goal of this work).

The VRT system was specifically designed using "retrofit" logic so that it could be adapted to any pressurized slurry tanker, i.e., equipped with a pressurized tank and a vacuum/pressure pump. This system is undoubtedly the most diffused spreading technology that is used in Italy. Moreover, this system can work with any distribution system, including a spreader plate, crawling nozzles, soil injectors, etc. The main goal of this research was to develop and to test in field conditions a system suitable for any existing new or old pressurized slurry tankers and to provide farmers with the ability to control the slurry application rate at each specific site in agreement with environmental regulations.

\section{THE SLURRY VRT SYSTEM}

A universal VRT system (fig. 1) was developed by the authors in cooperation with ARVATEC Ltd (Rescaldina, Milan, Italy). The system is composed of: $i$ ) a variablesection with a hydraulically actuated gate valve that can be adjusted to the outflow rate of the distributed slurry, ii) a slurry flow rate sensor, iii) a control computer that integrates a DGPS receiver with an I/O interface to control the gate valve opening, and $i v$ ) a mechanical interface that allows the installation of the system onto any slurry tanker.

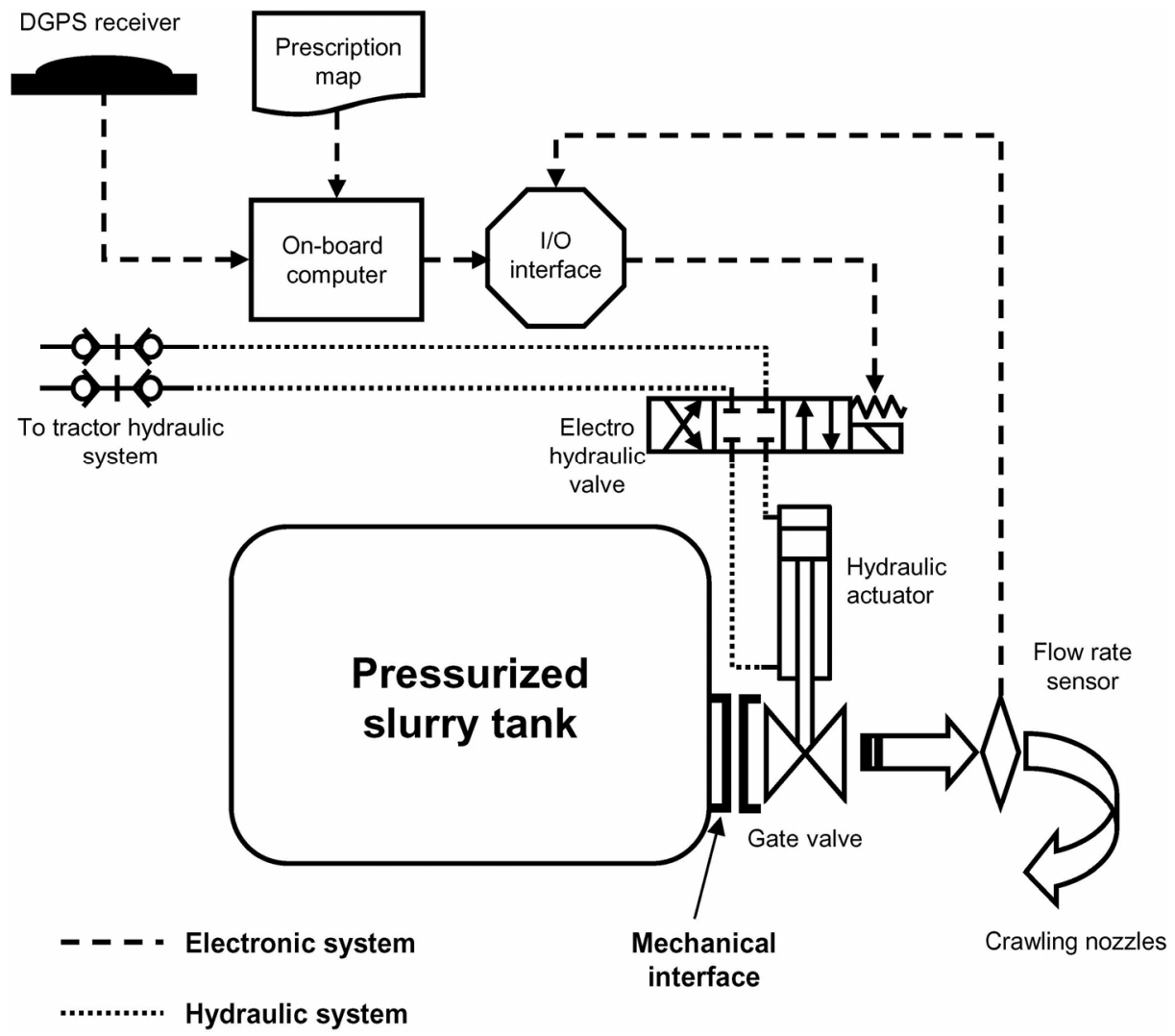

Figure 1. Block diagram of the VRT system. 


\section{THE VRT DEVICE}

The variable-rate distribution system is actuated by a variable-section gate valve (CEAP, Schio, Vicenza, Italy) (fig. 2) that is mounted on the outflowing bulkhead of a tanker.

The outlet section of the gate valve can be adjusted using a hydraulic cylinder. This adjustable gate valve allows the sectional area to be changed from 0 to $115 \mathrm{~cm}^{2}$. The piston position is controlled by a 3-way electrohydraulic valve (Oil Control - BoschRexroth, Nonantola, Modena, Italy) that is connected to the main hydraulic circuit of the coupled tractor.

\section{The SLURRY Flow RATe SENSOR}

The distributed flow of the slurry is measured in real time using a Doppler effect flow sensor (Echo FlowSwitch 600, Echo Process Instrumentation, Shalimar, Fla.). The ECHO FlowSwitch 600 is a liquid velocity meter designed for flow measurements on slurries, dirty water, and wastewater. It requires no programming or preliminary calibration. Velocity sensing range of $0-10 \mathrm{~m} / \mathrm{s}$ corresponds to an output of $0-6$ VDC proportionally $( \pm 1.0 \%$ nominal accuracy).

The Doppler sensor is positioned on the plastic pipe (internal diameter $0.12 \mathrm{~m}$ ) connecting the gate valve with the spreading device (fig. 3).
The measured voltage is linearly proportional to the fluid speed inside the pipe, as described by equation 1 :

$$
F s=V \cdot k
$$

where

$F_{S}=$ the average speed of the fluid inside the pipe $\left(\mathrm{m} \mathrm{s}^{-1}\right)$,

$V=$ the voltage output of the sensor $(\mathrm{V})$, and

$k=1.667 \mathrm{~m} \mathrm{~s}^{-1} \mathrm{~V}^{-1}$ is a fixed coefficient provided by the sensor producer.

Given A (the known cross-sectional area of the pipe, in our case, $\mathrm{A}=0.0113 \mathrm{~m}^{2}$ ), it is possible to obtain the flow rate $\left(Q_{v}, \mathrm{~m}^{3} \mathrm{~min}^{-1}\right)$ of the distributed slurry using equation 2 :

$$
Q_{v}=60 \cdot k \cdot A \cdot V
$$

\section{The CONTROL COMPUTER}

The overall system was controlled by a tractor-mounted industrial computer (ArvaPC, ARVATEC Ltd., Milan, Italy) that is based on an AMD processor $(500 \mathrm{MHz})$ with $512 \mathrm{Mb}$ RAM and a touch screen monitor (fig. 4a). The control computer uses a single frequency GPS receiver with a 12-channels (Hemisphere SX2, Hemisphere GPS, Calgary, Canada) and a differential correction. The I/O connection with the hardware is based on the ISO-BUS protocol.
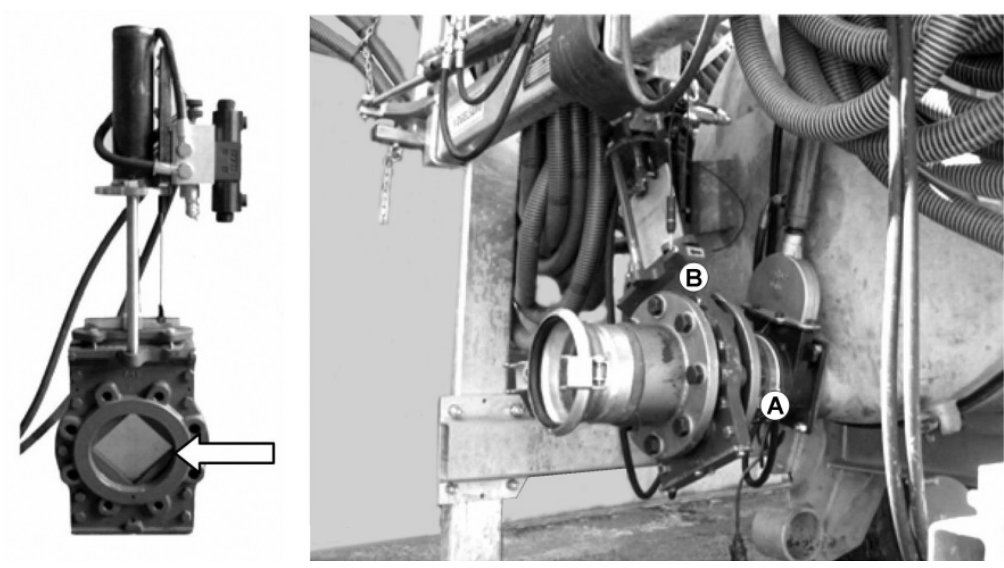

Figure 2. (Left) The developed VRT system; the arrow indicates the gate valve section. (Right) The VRT system that was mounted on a slurry tanker and used during the field experiments. (A) Mechanical interface, (B) gate valve.

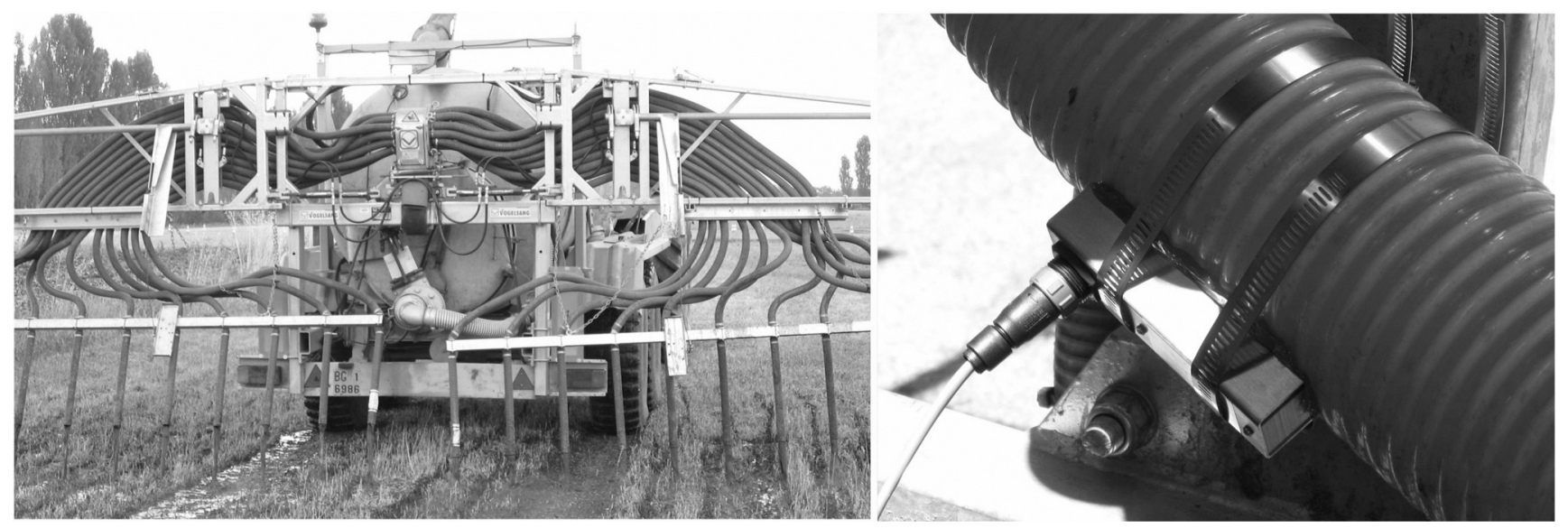

Figure 3. (Left) A tanker equipped with the VRT system during the field tests. (Right) A flow rate sensor mounted on the outgoing pipe. 

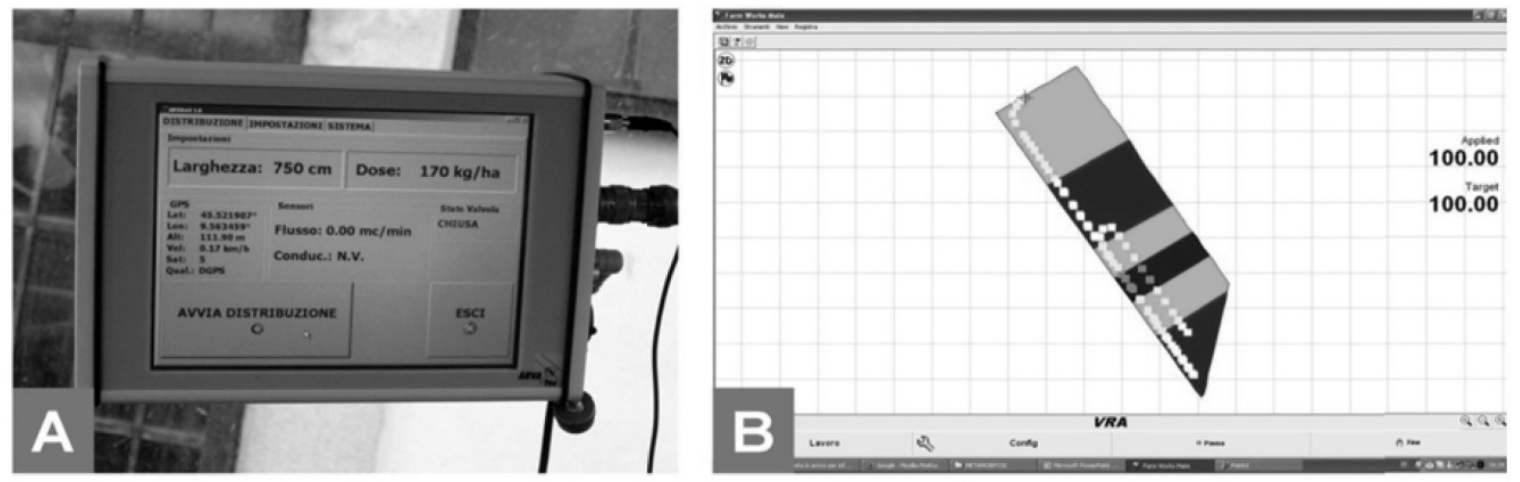

Figure 4. (A) The control computer on-board of a coupled tractor. (B) An example of a prescription map with different nominal rates of nitrogen application.

The computer uses custom-designed software to control the slurry spreading operations automatically following a pre-loaded digital prescriptive map and depending on the current tractor position in the field.

The VRT control software allows the operator to:

a) set the tanker working width, calibrate the slurry flow rate sensor, start and stop the variable rate distribution,

b) manually set the average nitrogen concentration in the distributed slurry if a sensor for measuring the in-line slurry nutrient content is not available;

c) load and edit the digital prescription maps (fig. 4b) that will be used to conduct the spreading operations, and

d) manually operate the distribution of nitrogen in the case of a system breakdown.

The software manages the offset between the GPS antenna and the crawling nozzle distribution device. Thus, the distribution is controlled by the real positions of the spreader nozzles on the prescription map. Finally, the software records the operating parameters in an exportable file that can be used to authenticate and trace the slurry spreading operations for compliance with regulations.

\section{SPREADING CONTROL LOGIC}

The control system operates based on feedback logic, which opens or closes the gate valve to obtain the desired slurry flow rate. At any time, this rate corresponds with the application rate that is prescribed by the map a teach position in the field.

Given a slurry nitrogen concentration of $\mathrm{cN}\left(\mathrm{kg} \mathrm{m}^{-3}\right)$, which is measured using an in-line sensor or obtained by laboratory analysis, the nitrogen application rate is (eq. 3):

$$
A R N=c N \cdot A R=c N \cdot \frac{Q_{v} \cdot 600}{w \cdot s}
$$

where

$A R N=$ the nitrogen application rate $\left(\mathrm{kg} \mathrm{ha}^{-1}\right)$,

$c N=$ the slurry nitrogen concentration $\left(\mathrm{kg} \mathrm{m}^{-3}\right)$,

$A R=$ the slurry application rate $\left(\mathrm{m}^{3} \mathrm{ha}^{-1}\right)$,

$Q_{v}=$ the slurry flow rate $\left(\mathrm{m}^{3} \mathrm{~min}^{-1}\right)$,

$w=$ the working width of the machine $(\mathrm{m})$, and

$s \quad=$ the forwarding speed of the tanker $\left(\mathrm{km} \mathrm{h}^{-1}\right)$.
Hence, if the map prescribes a specified nitrogen application rate $\mathrm{ARN}^{*}$ at a given field position, the control computer modulates the opening of the valve until the slurry flow sensor provides a voltage output (eq. 2) that corresponds with the outflow $\mathrm{Qv}^{*}$, as shown by the following equation (eq. 4):

$$
Q_{v}^{*}=\frac{A R N^{*}}{c N} \cdot \frac{w \cdot s}{600}
$$

\section{MeChaniCAL Retrofit INTERFACE}

The VRT device was specifically designed to fit any type of pressurized slurry tanker. Considering this objective, the gate valve module was outfitted with a mechanical interface (double flange) that easily allowed the original tank discharge unit and the new distributing unit to connect. Consequently, this VRT system can be used with any new or used farm slurry tanker.

\section{EXAMPLE OF APPLICATION ON A SLURRY TANKER}

To provide an example of operations, the developed VRT system was installed on a 20 year old, two-axis slurry tanker (Grazioli-Remac, Calvisano, Italy) that was equipped with a $10 \mathrm{~m}^{3}$ capacity tank (tank diameter: $1.5 \mathrm{~m}$ ). For this type of tanker, slurry loading and distribution are enabled by the tank's internal pressure generated by a compressor driven by the tractor's PTO. Internal pressure is maintained at $120 \mathrm{kPa}$ by a constant-pressure regulating system, which allows delivery of the slurry to the distribution system (Vogelsang Exacut, Hagen, Germany) through a plastic pipe with an inner diameter of $0.12 \mathrm{~m}$. Next, the distribution system feeds the 24 crawling nozzles (inner diameter $0.04 \mathrm{~m}$ ), resulting in a working width of $7.5 \mathrm{~m}$. This study only focused on the distribution of the crawling nozzles because environmental regulations tend to outlaw the use of other distribution systems (i.e., spreader plate, pressure nozzle) due to their potential for releasing ammonia into the atmosphere (Misselbrook et al., 2002; Mazzetto et al., 2012a).

\section{FieLd TESTS}

The VRT field distribution tests were conducted at the CRA-ING facility in Treviglio, Bergamo, Italy $\left(45^{\circ} 33^{\prime} 17.33^{\prime \prime} \mathrm{N}\right.$; 9 $\left.33^{\circ} 45.97^{\prime \prime} \mathrm{E}\right)$. The slurry tanker was 
coupled with a $118 \mathrm{~kW} 4 \mathrm{WD}$ tractor that was equipped with a continuously variable drive transmission. The computer control GPS rate was set at $1 \mathrm{~Hz}$.

Two different effluents were used for the field tests: a) the liquid fraction of a digestate obtained from a biogas plant that was fed with dairy livestock effluent, and b) raw swine slurry. For the VRT system configuration used in this study, a sensor for the on-line measurement of the nitrogen content was not used. Therefore, the average value of nitrogen measured in the laboratory (TKN, obtained with the Kjeldahl Method) was manually set as the nitrogen content in the control software.

Spreading trials were conducted at three different nitrogen application rates $\left(170,250\right.$ and $\left.340 \mathrm{~kg} \mathrm{ha}^{-1}\right)$ at two different forward speeds $\left(2\right.$ and $\left.3 \mathrm{~km} \mathrm{~h}^{-1}\right)$. This speed range is common for slurry distribution with crawling nozzles at high application rate, such as in European regions where intensive livestock is associated to arable crops farming (Bodria et al., 2013; Gioelli et al., 2014).

Field tests were conducted on a flat field that was divided into single plots with a length of $50 \mathrm{~m}$. Each distribution test was conducted for an area of $375 \mathrm{~m}^{2}(50 \mathrm{~m}$ $\times 7.5 \mathrm{~m}$ of working width) by driving the slurry tanker on a straight pass through the plot. Each plot was identified using topographic stakes, and their coordinates were acquired using a DGPS. This procedure allowed us to set a digital prescription map that could be loaded into the control computer's memory prior to the experiments. All of the field tests were conducted in triplicate (three repeated independent passes) according to the experimental protocol summarized in table 1.

In each plot, three rows (A, B, C, see fig. 5 for reference) of interception trays (sized $0.5 \times 0.5 \times 0.1 \mathrm{~m}$ ) were positioned on the ground at a distance interval of $10 \mathrm{~m}$ transverse to the direction of travel. Along each row, six trays ( 1 to 6 , see fig. 5 for reference) were positioned for collecting the distributed slurry.

Table 1. The experimental protocol for slurry distribution.

\begin{tabular}{ccc}
\hline Test & $\begin{array}{c}\text { Nominal Nitrogen Application } \\
\text { Rate }\left(\mathrm{kg} \mathrm{ha}^{-1}\right)\end{array}$ & $\begin{array}{c}\text { Forward Speed } \\
\left(\mathrm{km} \mathrm{h}^{-1}\right)\end{array}$ \\
\hline P1 & 170 & 2 \\
P2 & 250 & 3 \\
P3 & 340 & 2 \\
P4 & & 2 \\
\hline
\end{tabular}

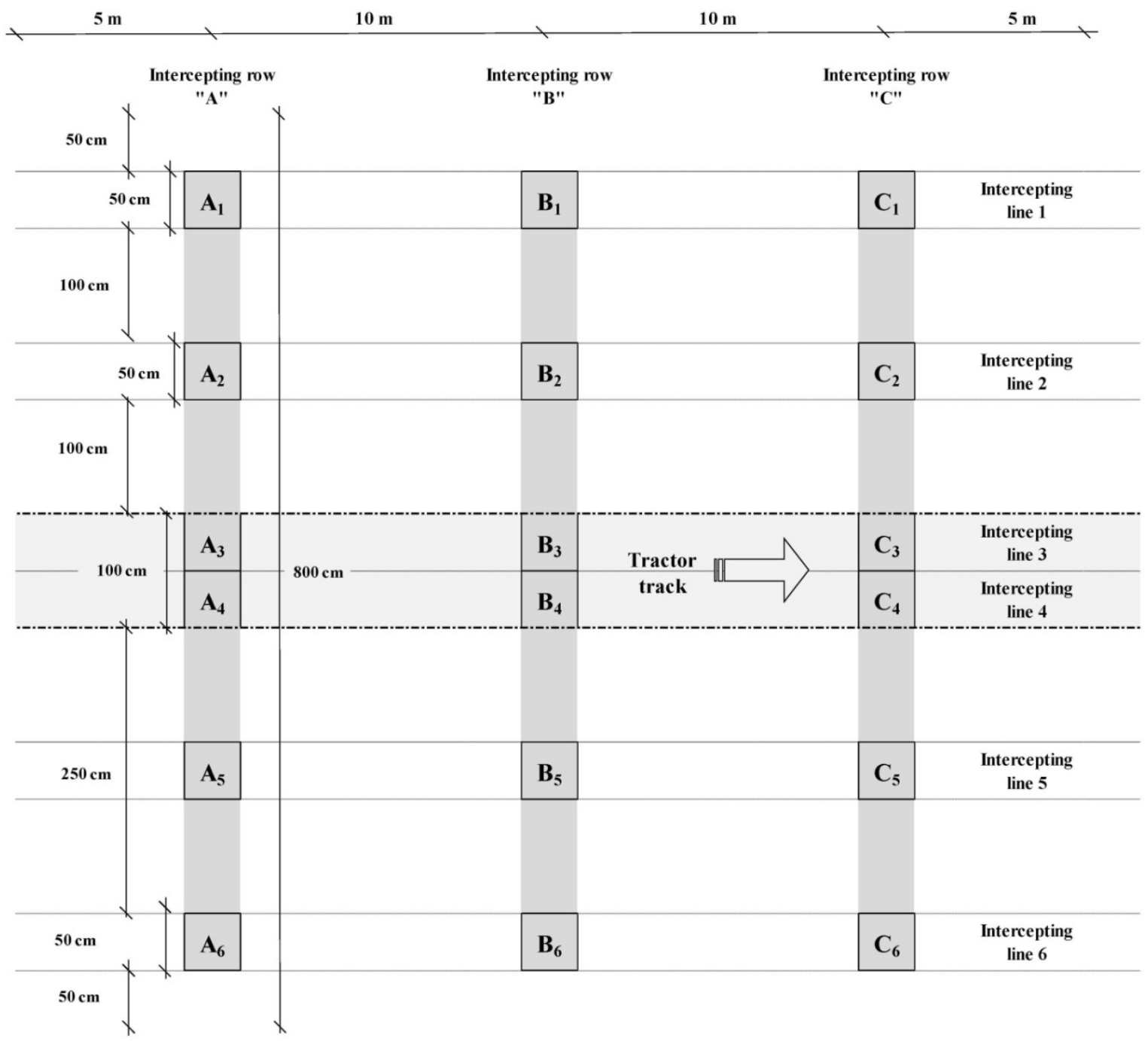

Figure 5. Diagram showing the positions of the sampling trays during the field experiments. 
Immediately after each distribution experiment, the trays were collected from the field and the following data were measured:

a) the volume of the slurry intercepted by each tray using a graduated cylinder,

b) the average density of the slurry using a graduated cylinder and a precision balance (Radwag, mod 6/C1/R, Radom, Poland, according to Thygesen et al., 2012),

c) the Total Nitrogen content (TKN) according to the Kjeldahl Method, and

d) the actual mass of the distributed slurry based on the gross weight difference of the slurry before and after distribution using a weighbridge with a resolution of $\pm 5 \mathrm{~kg}$ (Società Cooperativa Bilanciai, mod. 800, Campogalliano, Italy).

All measurements were conducted in triplicate.

\section{Data Processing}

The measured data were statistically processed to evaluate the differences between the nominal and actual amounts of the distributed slurry and to assess the VRT system performance and precision achieved under the considered experimental conditions. Data processing was performed using MINITAB 17.0 (Minitab, 2010).

\section{VRT System Performance Assessment}

The VRT system performance shows the ability of the system to control the slurry outflow rate under different operating conditions. The acquired data were processed using an analysis of variance (ANOVA) that applied a generalized linear model (GLM). The forward speeds $\left(2\right.$ and $\left.3 \mathrm{~km} \mathrm{~h}^{-1}\right)$ and the nitrogen application rates (170, 250 , and $340 \mathrm{~kg} \mathrm{ha}^{-1}$ ) were assumed to be fixed; the distributed amount of slurry $\left(\mathrm{g} \mathrm{tray}^{-1}\right)$ was the dependent variable, and the slurry density was assumed to be the balancing variable. To evaluate with specific depth the operating case corresponding to vulnerable zones spreading (threshold: $\left.170 \mathrm{~kg} \mathrm{ha}^{-1}\right)$, the effects of tractor speed $\left(\mathrm{km} \mathrm{h}^{-1}\right)$ on nominal application rate of $170 \mathrm{~kg} \mathrm{ha}^{-1}$ were tested using a one-way ANOVA. The homogeneity of the variances was evaluated using a Levene test $(\mathrm{P}<0.05)$.

\section{Precision Distribution Analysis}

The precision distribution is the capability of the system to apply slurry to a field uniformly based on a nominal application rate. In this study, the precision distribution was assessed according to the UNI-EN 13406:2002 standard, which specifies requirements for slurry tankers that spread animal slurry for agricultural purposes. In particular, this standard specifies the procedures that should be used to determine the transverse and longitudinal spreading characteristics under field conditions.

\section{Longitudinal Distribution Test}

The longitudinal performance of spreading was assessed by an average slurry flow rate $\left(\mathrm{Q}_{\mathrm{a}}\right)$ that was computed according to the following equation (eq. 5):

$$
Q_{a}=\frac{1}{n} \sum_{i=1}^{n} Q_{i}
$$

where

$Q_{a}=$ the average mass flow of the experimental run $\left(\mathrm{kg} \mathrm{s}^{-1}\right)$,

$n=$ the number of samples along the distribution direction, and

$Q_{i}=$ the mass flow at each sample position $i\left(\mathrm{~kg} \mathrm{~s}^{-1}\right)$.

The individual values of $\mathrm{Q}_{i}$ for each row were evaluated as the ratio between the mass collected with the aligned trays and the time necessary to travel a distance of one tray size $(0.5 \mathrm{~m})$.

\section{Transverse Distribution Uniformity}

The transverse uniformity of distribution was determined by computing the deviation of the applied amount of slurry at a specific position of the tanker pass from the mean value (eq. 6):

$$
\operatorname{Dev}_{\%}=100 \cdot \frac{\sum_{i=1}^{n}\left|m_{i}-\bar{m}\right|}{n \cdot \bar{m}}
$$

where

Dev $_{\%}=$ the transverse deviation of the distributed slurry,

$n=$ the number of trays along each row in a direction that is transverse to the travelling direction,

$m_{i} \quad=$ the mass of slurry intercepted by each tray, and

$\bar{m} \quad=$ the average of the mass intercepted along each row.

The deviations that were obtained were processed using a one-way ANOVA to estimate the possible influence of the nominal application rate.

\section{RESUltS AND DISCUSSION}

The physico-chemical characteristics of the slurry used during the spreading experiments were determined in the laboratory. The dairy digestate liquid fraction (DDLF) had a density of $1.010 \pm 0.001 \mathrm{~kg} \mathrm{dm}^{-3}$ and an average nitrogen content of $3.79 \pm 0.02 \mathrm{~kg} \mathrm{~m}^{-3}$ while the raw swine slurry (RSS) had a density of $1.003 \pm 0.001 \mathrm{~kg} \mathrm{dm}^{-3}$ and an average nitrogen content of $3.04 \pm 0.03 \mathrm{~kg} \mathrm{~m}^{-3}$ (table 2). These values are well within the range of previously reported tests (CRPA, 2012; Negri and Maggiore, 2012; Brambilla et al., 2013; Chiumenti et al., 2013). An analysis of the data showed that the density and nitrogen content were not significantly dependent on the distribution conditions, indicating that the tanker was able to maintain the homogeneity of the slurry during the field operations.

\section{ANALYSIS OF VRT PERformanCE}

Table 3 summarizes the results of all the experimental runs. The average forward speed of the tanker $(2.04 \pm 0.05$ $\mathrm{km} \mathrm{h}^{-1}$ and $3.05 \pm 0.06 \mathrm{~km} \mathrm{~h}^{-1}$ ) and the distances travelled during distribution were obtained by processing the DGPS data. Overall, the differences between the total applied slurry mass and the nominal value varied from $0.3 \%$ (DP23 test) to $8.4 \%$ (DP3-2 test). The DGPS allowed us to 
Table 2. The physico-chemical properties of the slurry used in the spreading experiments.

\begin{tabular}{|c|c|c|c|c|c|}
\hline \multirow[b]{2}{*}{ Trial } & \multirow[b]{2}{*}{$\begin{array}{c}\text { Forward Speed } \\
\quad\left(\mathrm{km} \mathrm{h}^{-1}\right)\end{array}$} & \multicolumn{2}{|c|}{ Dairy Digestate Clarified Fraction } & \multicolumn{2}{|c|}{ Raw Swine Slurry } \\
\hline & & $\begin{array}{c}\text { Density } \\
\left(\mathrm{kg} \mathrm{dm}^{-3}\right)\end{array}$ & $\begin{array}{c}\text { TKN } \\
\left(\mathrm{g} \mathrm{kg}^{-1}\right)\end{array}$ & $\begin{array}{c}\text { Density } \\
\left(\mathrm{kg} \mathrm{dm}^{-3}\right)\end{array}$ & $\begin{array}{c}\text { TKN } \\
\left(\mathrm{g} \mathrm{kg}^{-1}\right)\end{array}$ \\
\hline Before spreading & & $1.010 \pm 0.001$ & $3.79 \pm 0.02$ & $1.003 \pm 0.001$ & $3.04 \pm 0.03$ \\
\hline After spreading (170 kg/ha) & $\begin{array}{l}2 \\
3\end{array}$ & $\begin{array}{l}1.010 \pm 0.007 \\
1.000 \pm 0.001\end{array}$ & 3.78 & $\begin{array}{l}0.998 \pm 0.003 \\
1.010 \pm 0.002\end{array}$ & 3.05 \\
\hline After spreading $(250 \mathrm{~kg} / \mathrm{ha})$ & 2 & $1.000 \pm 0.050$ & 3.79 & $0.990 \pm 0.060$ & 3.02 \\
\hline After spreading $(340 \mathrm{~kg} / \mathrm{ha})$ & 2 & $1.010 \pm 0.001$ & 3.82 & $1.012 \pm 0.002$ & 3.06 \\
\hline
\end{tabular}

Table 3. The overall results of the spreading experiments with dairy digestate clarified fraction (above) and with raw swine slurry (below).

\begin{tabular}{|c|c|c|c|c|c|c|}
\hline \multicolumn{7}{|c|}{ Dairy Digestate Clarified Fraction } \\
\hline Test & $\begin{array}{l}\text { Nitrogen } \\
\text { Amount } \\
\left(\mathrm{kg} \mathrm{ha}^{-1}\right)\end{array}$ & $\begin{array}{c}\text { Average } \\
\text { Forward Speed } \\
\left(\mathrm{km} \mathrm{h}^{-1}\right) \\
\end{array}$ & $\begin{array}{c}\text { Actual } \\
\text { Spreading Pass } \\
(\mathrm{m})\end{array}$ & $\begin{array}{c}\text { Expected Amount } \\
\text { of Slurry } \\
\left(\mathrm{m}^{3} \mathrm{ha}^{-1}\right)\end{array}$ & $\begin{array}{c}\text { Measured Amount } \\
\text { of Slurry } \\
\left(\mathrm{m}^{3} \mathrm{ha}^{-1}\right)\end{array}$ & $\begin{array}{c}\text { Deviation } \\
\% \\
\end{array}$ \\
\hline DP1-1 & \multirow{6}{*}{170} & 2.13 & 49.70 & \multirow{3}{*}{44.70} & 41.98 & -6.10 \\
\hline DP1-2 & & 2.08 & 49.60 & & 42.50 & -4.92 \\
\hline DP1-3 & & 2.12 & 50.07 & & 44.08 & -1.38 \\
\hline DP2-1 & & 3.03 & 50.40 & \multirow{3}{*}{44.70} & 42.01 & -6.01 \\
\hline DP2-2 & & 3.10 & 49.85 & & 41.33 & -7.53 \\
\hline DP2-3 & & 2.99 & 50.35 & & 44.84 & +0.31 \\
\hline DP3-1 & \multirow{3}{*}{250} & 1.98 & 50.60 & \multirow{3}{*}{65.80} & 60.67 & -7.80 \\
\hline DP3-2 & & 1.95 & 50.22 & & 60.25 & -8.44 \\
\hline DP3-3 & & 2.02 & 49.90 & & 62.64 & -4.80 \\
\hline DP4-1 & \multirow{3}{*}{340} & 2.01 & 50.25 & \multirow{3}{*}{89.50} & 83.65 & -6.54 \\
\hline DP4-2 & & 2.05 & 50.22 & & n.a. ${ }^{[\mathrm{a}]}$ & n.a. ${ }^{[a]}$ \\
\hline DP4-3 & & 2.03 & 50.15 & & 92.13 & +2.94 \\
\hline \multicolumn{7}{|c|}{ Raw Swine Slurry } \\
\hline Test & $\begin{array}{l}\text { Nitrogen } \\
\text { Amount } \\
\left(\mathrm{kg} \mathrm{ha}^{-1}\right)\end{array}$ & $\begin{array}{c}\text { Average } \\
\text { Forward Speed } \\
\left(\mathrm{km} \mathrm{h}^{-1}\right)\end{array}$ & $\begin{array}{c}\text { Actual } \\
\text { Spreading Pass } \\
(\mathrm{m})\end{array}$ & $\begin{array}{c}\text { Expected Amount } \\
\text { of Slurry } \\
\left(\mathrm{m}^{3} \mathrm{ha}^{-1}\right)\end{array}$ & $\begin{array}{c}\text { Measured Amount } \\
\text { of Slurry } \\
\left(\mathrm{m}^{3} \mathrm{ha}^{-1}\right)\end{array}$ & $\begin{array}{c}\text { Deviation } \\
\% \\
\end{array}$ \\
\hline SP1-1 & \multirow{6}{*}{170} & 2.03 & 50.70 & \multirow{3}{*}{56.70} & 57.54 & +1.49 \\
\hline SP1-2 & & 2.09 & 49.83 & & 53.07 & -6.40 \\
\hline SP1-3 & & 2.11 & 50.10 & & 54.23 & -4.36 \\
\hline SP2-1 & & 3.12 & 50.15 & \multirow{3}{*}{44.70} & 54.25 & -4.33 \\
\hline SP2-2 & & 3.08 & 50.34 & & 59.54 & +5.01 \\
\hline $\mathrm{SP} 2-3$ & & 2.98 & 49.97 & & 59.27 & +4.53 \\
\hline SP3-1 & \multirow{3}{*}{250} & 2.01 & 50.13 & \multirow{3}{*}{83.30} & 86.39 & +3.71 \\
\hline SP3-2 & & 2.05 & 50.12 & & 86.87 & +4.29 \\
\hline SP3-3 & & 2.00 & 50.31 & & 83.91 & +0.74 \\
\hline SP4-1 & \multirow{3}{*}{340} & 2.07 & 49.96 & \multirow{3}{*}{113.30} & 115.56 & +1.99 \\
\hline SP4-2 & & 2.02 & 50.01 & & 117.74 & +3.92 \\
\hline SP4-3 & & 2.04 & 50.18 & & 118.67 & +4.74 \\
\hline
\end{tabular}

${ }^{[\mathrm{a}]}$ Data rejected in post processing due to failure of the hydraulic system of the tractor

position the spreading areas accurately, with actual spreading passes lengths of between 49.60 of the DP1-2 test and $50.70 \mathrm{~m}$ of the SP1-1 test (nominal length: $50 \mathrm{~m}$ ).

Results from the two-way ANOVAs are shown in table 4. As expected, the nominal rate of nitrogen application significantly affected the amount of effluent (both DDLF and RSS) collected by the trays. In contrast, the forward speed did not influence the slurry spread, which confirmed the reliability of the VRT system for controlling the amount of slurry that was distributed in the field.

This is further highlighted in tables 5 and 6, where the results of the post-hoc comparisons are shown for the nominal application rate and the forward speed based on the Fisher's LSD test $(\mathrm{P}<0.05)$. Again, the analysis confirms that the VRT system was capable of controlling the spreading based on the application rate and regardless of the travelling speed.

Table 4. ANOVA table of the generalized linear model.

\begin{tabular}{|c|c|c|c|c|c|c|c|c|}
\hline \multirow[b]{2}{*}{ Experimental factors } & \multicolumn{4}{|c|}{ Dairy Digestate Liquid Fraction } & \multicolumn{4}{|c|}{ Raw Swine Slurry } \\
\hline & $\begin{array}{c}\text { Degree of } \\
\text { Freedom }\end{array}$ & $\mathrm{F}$ & Sig. ${ }^{[a]}$ & $\begin{array}{c}\text { Eta } \\
\text { squared }\end{array}$ & $\begin{array}{l}\text { Degree of } \\
\text { Freedom }\end{array}$ & $\mathrm{F}$ & Sig. ${ }^{[\mathrm{a}]}$ & $\begin{array}{c}\text { Eta } \\
\text { squared }\end{array}$ \\
\hline Intercept & 1 & 3554.30 & 0.000 & 0.935 & 1 & 55.50 & 0.000 & 0.987 \\
\hline Forward Speed & 1 & 1.47 & 0.226 & 0.037 & 1 & 0.76 & 0.386 & 0.010 \\
\hline Nominal application rate & 2 & 57.83 & 0.000 & 0.294 & 2 & 196.25 & 0.000 & 0.270 \\
\hline Speed $*$ Application rate & 0 & & & 0.000 & 0 & & & 0.000 \\
\hline Error & 176 & & & & 212 & & & \\
\hline Total & 180 & & & & 215 & & & \\
\hline \multirow[t]{2}{*}{$\underline{\text { Corrected total }}$} & 179 & & & & 214 & & & \\
\hline & \multicolumn{2}{|c|}{$\mathrm{R}^{2}: 71.9 \%$} & \multicolumn{2}{|c|}{$\mathrm{R}^{2}$ (adj.) $=71.4 \%$} & \multicolumn{2}{|c|}{$\mathrm{R}^{2}: 70.8 \%$} & \multicolumn{2}{|c|}{$\mathrm{R}^{2}$ (adj.) $=69.7 \%$} \\
\hline
\end{tabular}

[a] A significance ( $\mathrm{Sig}$ ) of less than 0.05 corresponds to variables that are statistically related to the amount of slurry that was collected using trays. 
Table 5. The average values ( \pm standard error) of the collected slurry in the sampling positions $\left(\mathrm{g}\right.$ tray $\left.{ }^{-1}\right)$ and the corresponding applied rates $\left(\mathrm{kg} \mathrm{ha}^{-1}\right)$ for different nominal applications.

\begin{tabular}{|c|c|c|c|c|}
\hline \multirow[b]{2}{*}{$\begin{array}{c}\text { Nitrogen Amount } \\
\left(\mathrm{kg} \mathrm{ha}^{-1}\right)\end{array}$} & \multicolumn{2}{|c|}{ Dairy Digestate Liquid Fraction $^{[\mathrm{a}]}$} & \multicolumn{2}{|c|}{ Raw Swine Slurry ${ }^{[a]}$} \\
\hline & $\begin{array}{l}\text { Collected Amount } \\
\left(\mathrm{g} \text { tray }^{-1}\right)\end{array}$ & $\begin{array}{l}\text { Applied Rate } \\
\left(\mathrm{kg} \mathrm{ha}^{-1}\right)\end{array}$ & $\begin{array}{l}\text { Collected Amount } \\
\left(\mathrm{g}_{\text {tray }}{ }^{-1}\right)\end{array}$ & $\begin{array}{l}\text { Applied Rate } \\
\left(\mathrm{kg} \mathrm{ha}^{-1}\right)\end{array}$ \\
\hline 170 & $1133.5 \pm 315.2 \mathrm{a}$ & $171.6 \pm 47.0 \mathrm{a}$ & $1407.9 \pm 298.4 \mathrm{a}$ & $171.2 \pm 36.3 \mathrm{a}$ \\
\hline 250 & $1659.2 \pm 367.8 b$ & $251.7 \pm 55.7 b$ & $2143.2 \pm 390.4 b$ & $260.6 \pm 47.5 b$ \\
\hline 340 & $2324.0 \pm 593.0 \mathrm{c}$ & $352.3 \pm 89.9 \mathrm{c}$ & $2933.2 \pm 582.5 \mathrm{c}$ & $356.7 \pm 70.8 \mathrm{c}$ \\
\hline
\end{tabular}

Different letters refer to significantly different averages $(\mathrm{P}<0.05)$.

Table 6. The average values ( \pm standard error) of the collected slurry in the sampling positions $\left(\mathrm{g} \mathrm{tray}^{-1}\right)$ and the corresponding applied rates $\left(\mathrm{kg} \mathrm{ha}^{-1}\right)$ at different working speeds and an application rate of $170 \mathrm{~kg} \mathrm{ha}^{-1}$.

\begin{tabular}{|c|c|c|c|c|}
\hline \multirow[b]{2}{*}{$\begin{array}{c}\text { Forward Speed } \\
\left(\mathrm{km} \mathrm{h}^{-1}\right)\end{array}$} & \multicolumn{2}{|c|}{ Dairy Digestate Liquid Fraction $^{[\mathrm{a}]}$} & \multicolumn{2}{|c|}{ Raw Swine Slurry $^{[\mathrm{a}]}$} \\
\hline & $\begin{array}{l}\text { Collected Amount } \\
\left(\mathrm{g}_{\text {tray }}{ }^{-1}\right)\end{array}$ & $\begin{array}{l}\text { Applied Rate } \\
\left(\mathrm{kg} \mathrm{ha}^{-1}\right)\end{array}$ & $\begin{array}{l}\text { Collected Amount } \\
\left(\mathrm{g}_{\text {tray }}{ }^{-1}\right)\end{array}$ & $\begin{array}{l}\text { Applied Rate } \\
\left(\mathrm{kg} \mathrm{ha}^{-1}\right)\end{array}$ \\
\hline 2 & $1190.8 \pm 241.2 \mathrm{a}$ & $180.4 \pm 36.4 \mathrm{a}$ & $1373.7 \pm 240.8 \mathrm{a}$ & $167.0 \pm 29.3 \mathrm{a}$ \\
\hline 3 & $1114.2 \pm 335.8 \mathrm{~b}$ & $169.0 \pm 50.8 \mathrm{a}$ & $1442.1 \pm 345.6 \mathrm{a}$ & $175.4 \pm 42.0 \mathrm{a}$ \\
\hline
\end{tabular}

[a] Different letters refer to significantly different averages $(\mathrm{P}<0.05)$.

Moreover, the possible effects of the single tray positions on rows (A to C) and on lines (1 to 6) (fig. 5) were investigated using a specific analysis of variance. The results, reported in table 7 and figure 6, show that trays positions did not significantly affect the intercepted amount of DDLF while, with reference to RSS, both the collected amount of slurry and the nominal application rate significantly increase passing from the row of trays "A" to "C" (table 7) while, as shown in figure 6, the tray line was not found to significantly affect RSS intercepted amounts and nitrogen rates.

\section{Precision Distribution Analysis \\ Longitudinal Distribution}

The longitudinal distribution, which was measured along the travelling direction and compared with the nominal values, was measured for all of the experimental conditions, as shown in figure 7 . The results show that, for

Table 7. The average values ( \pm standard error) of the collected slurry along the sampling rows $\left(\mathrm{g} \mathrm{tray}^{-1}\right)$ and the corresponding applied rates $\left(\mathrm{kg} \mathrm{ha}^{-1}\right)$ for a nominal application of $170 \mathrm{~kg} \mathrm{ha}^{-1}$.

\begin{tabular}{|c|c|c|c|c|}
\hline \multirow[b]{2}{*}{ Row of Sampling Trays } & \multicolumn{2}{|c|}{ Dairy Digestate Liquid Fraction $^{[\mathrm{a}]}$} & \multicolumn{2}{|c|}{ Raw Swine Slurry $^{[\mathrm{a}]}$} \\
\hline & $\begin{array}{l}\text { Collected Amount } \\
\left(\mathrm{g} \mathrm{tray}^{-1}\right)\end{array}$ & $\begin{array}{c}\text { Applied Rate } \\
\left(\mathrm{kg} \mathrm{ha}^{-1}\right)\end{array}$ & $\begin{array}{c}\text { Collected Amount } \\
\left(\mathrm{g} \mathrm{tray}^{-1}\right)\end{array}$ & $\begin{array}{c}\text { Applied Rate } \\
\left(\mathrm{kg} \mathrm{ha}^{-1}\right)\end{array}$ \\
\hline $\mathrm{A}$ & $1057.1 \pm 159.2 \mathrm{a}$ & $160.3 \pm 24.3 \mathrm{a}$ & $1334.2 \pm 226.6 \mathrm{a}$ & $162.2 \pm 27.6 \mathrm{a}$ \\
\hline B & $1139.6 \pm 399.1 \mathrm{a}$ & $172.8 \pm 60.6 \mathrm{a}$ & $1371.7 \pm 322.3 \mathrm{a}, \mathrm{b}$ & $166.8 \pm 39.2 \mathrm{a}, \mathrm{b}$ \\
\hline $\mathrm{C}$ & $1203.4 \pm 332.2 \mathrm{a}$ & $182.3 \pm 50.4 \mathrm{a}$ & $1517.9 \pm 312.5 \mathrm{~b}$ & $184.6 \pm 38.0 \mathrm{~b}$ \\
\hline
\end{tabular}

[a] Different letters account for significantly different averages $(\mathrm{P}<0.05)$.

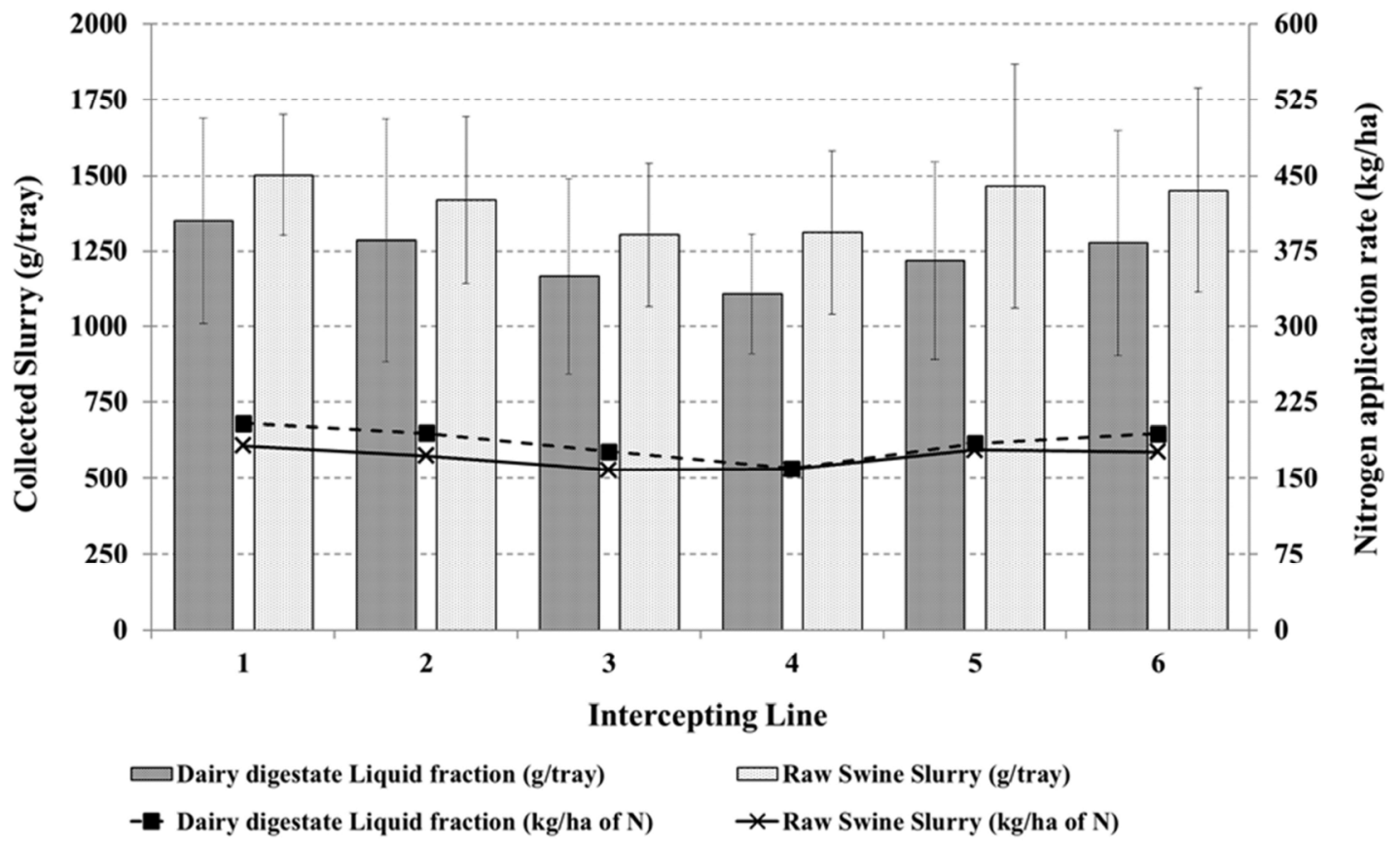

Figure 6. Average values ( \pm standard error) of the collected slurry along the sampling lines $\left(\mathrm{g}\right.$ tray $\left.{ }^{-1}\right)$ and the corresponding applied rates $\left(\mathrm{kg} \mathrm{ha}^{-1}\right)$ for a nominal application of $170 \mathrm{~kg} \mathrm{ha}^{-1}$. Charts refer both to dairy digestate liquid fraction and raw swine slurry. 

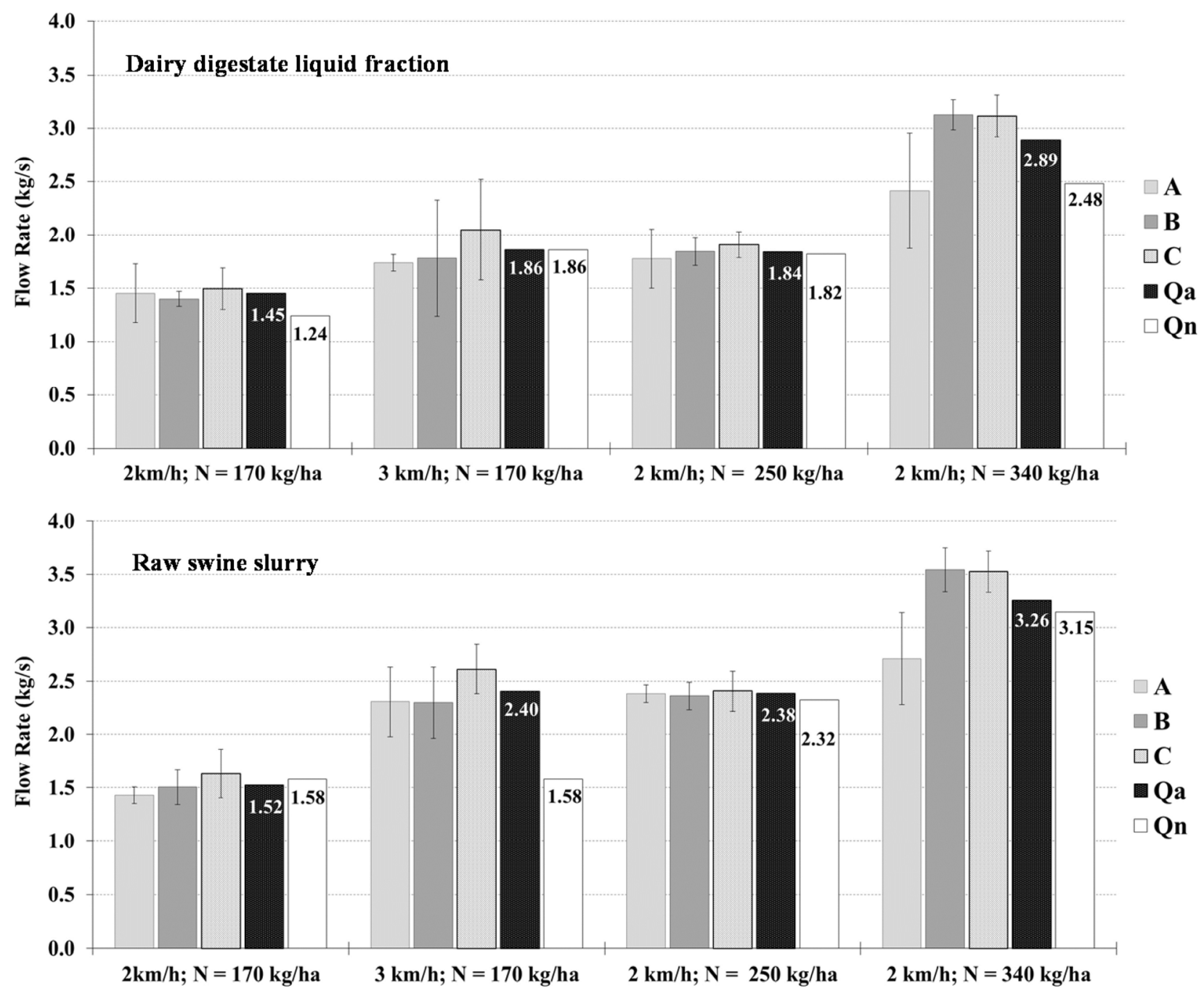

Figure 7. Slurry flow rates measured along the three sampling rows $(A, B, C)$ and the average outflow $\left(Q_{a}\right)$ under different operating conditions compared to the nominal slurry flow rate $\left(Q_{n}\right)$.

both DDLF and RSS, the system performed uniformly based on three (A, B, C) sampling positions along each pass. Indeed, the variability of the resulting flow rate values ranged from $5 \%$ to $22 \%$.

Moreover, the ability of the VRT system to control the slurry flow rate accurately enough, allowed us to limit the overall average error from the nominal value to less than $15 \%$. For both the considered effluents the best results were obtained for the mid-range of the tested conditions (i.e., speed $=3 \mathrm{~km} \mathrm{~h}^{-1}$ combined with an $\mathrm{AR}=170 \mathrm{~kg} \mathrm{ha}^{-1}$; and speed $=2 \mathrm{~km} \mathrm{~h}^{-1}$ combined with an $\mathrm{AR}=250 \mathrm{~kg} \mathrm{ha}^{-1}$ ), with an average deviation of approximately $1 \%$ between the actual and the nominal flow rates. This behavior was most likely related to the superior response of the gate valve when operating within its linear range (i.e., away from closed and fully open positions).

\section{Transverse Distribution Uniformity}

Table 8 lists the results of the transverse uniformity tests as indicated by the percent deviation in the distributed amount of slurry (eq. 6). For all of the experiments, the system allowed us to limit the average deviation of the spread amount to within $20 \%$. In particular, the homogenei- ty of the distribution slurry was slightly better at a forward speed of $2 \mathrm{~km} \mathrm{~h}^{-1}$, and reached the best uniformity of Dev\% $=14.2 \pm 0.8 \%$ for DDLF distributed at the nominal application rate of $170 \mathrm{~kg} \mathrm{ha}^{-1}$ while in case of RSS, the best uniformity is achieved distributing $250 \mathrm{~kg} \mathrm{ha}^{-1}$ of $\mathrm{N}$ at $2 \mathrm{~km} \mathrm{~h}^{-1}$. Moreover, based on the measurement data, the forward speed and the application rate did not significantly influence the uniformity of the distributions.

\section{CONClusions}

In this work, a variable rate distribution system for slurry was developed and tested using field experiments.

Table 8. The average transverse deviation (Dev.\%) that was measured under the different operative conditions.

\begin{tabular}{|c|c|c|c|}
\hline \multirow{2}{*}{$\begin{array}{l}\text { Forward } \\
\text { Speed } \\
\left(\mathrm{km} \mathrm{h}^{-1}\right)\end{array}$} & \multirow{2}{*}{$\begin{array}{l}\text { Nitrogen } \\
\text { Amount } \\
\left(\mathrm{kg} \mathrm{ha}^{-1}\right)\end{array}$} & $\begin{array}{c}\text { Dairy Digestate } \\
\text { Liquid Fraction }^{[a]}\end{array}$ & $\begin{array}{c}\text { Raw Swine } \\
\text { Slurry }\end{array}$ \\
\hline & & Dev.\% & Dev.\% \\
\hline \multirow{3}{*}{2} & 170 & $14.2 \pm 0.78 \mathrm{a}$ & $13.4 \pm 1.4 \mathrm{a}$ \\
\hline & 250 & $16.4 \pm 7.63 \mathrm{a}$ & $11.0 \pm 1.3 \mathrm{a}$ \\
\hline & 340 & $13.7 \pm 9.20 \mathrm{a}$ & $15.3 \pm 1.6 \mathrm{a}$ \\
\hline 3 & 170 & $20.4 \pm 9.23 \mathrm{a}$ & $15.2 \pm 1.8 \mathrm{a}$ \\
\hline
\end{tabular}

[a] Different letters are related to significantly different averages $(\mathrm{P}<0.05)$ 
The system was designed according to a retrofit approach (i.e., as a self-standing module that can be adapted and mounted on existing pressurized slurry tanker equipment).

The developed VRT system was mounted on a used tanker with a crawling nozzle distribution system and was tested according to standard procedures (UNI EN 13406:2002) to evaluate its performance at varying forward speeds and nitrogen application rates. Overall, the system applied an amount of slurry (on average along each pass) that deviated from the nominal value by less than $9 \%$. Furthermore, the system was able to apply a site-specific amount of slurry (set at each sampling position) that deviated from the nominal values by less than $15 \%$.

The best results were generally obtained under midrange operating conditions (i.e., higher speeds with lower application rates, as well as lower speeds with higher application rates), for which the measured average deviation was approximately $1 \%$ between the actual and the nominal distributed rates.

In addition, in the transverse direction, the distribution was uniform, with an overall average deviation of less than $20 \%$ for the distributed slurry. Furthermore, the forward speed and the application rate did not appear to affect the uniformity of the slurry distribution.

This type of VRT system may interest farmers who require a better management system for applying slurry with fertilizing properties while complying with increasingly strict regulations. Indeed, this VRT system appears to be a sustainable solution that could be adapted to any operating tanker for the distribution of animal slurry for agriculture. Moreover, the real time, automatic savings of the parameters that were used during the slurry distribution operations enables farmers to document their activity easily and objectively in case of an audit or other potential controversy.

\section{ACKNOWLEDGMENTS}

This work was conducted within the framework of the "SINBION" project (Development of sustainable integrated systems for the recovery of agricultural and agro-industry by-products to optimize biogas production and to enhance the agronomic use of digestate) and was funded by the Italian Ministry of Agricultural, Environmental and Forestry Policies (Ministry Decree $n^{\circ}$ 27335/7303/10) under the Scientific coordination of Prof. Pierluigi Navarotto, an ASABE member (University of Milan, Veterinary Sciences Faculty, Department of Health, Animal Science and Food Safety).

The authors would also like to acknowledge the valuable contributions of Mr. Elia Premoli (CRA-ING, Laboratory of Treviglio), who set up and performed the spreading operations, and Dr. Emanuele Marchesi (Az. Agr. Carioni, Trescore Cremasco, Italy), who supplied the clarified digestate fraction.

\section{REFERENCES}

Balsari, P., Airoldi, G., \& Gioelli, F. (2005). Improved recycling of livestock slurries on maize by means of a modular tanker and spreader. Biores. Tech., 96(2), 229-234. http://dx.doi.org/10.1016/j.biortech.2004.05.012.

Bodria, L., Pellizzi, G., \& Piccarolo, P. (2013). Meccanica Agraria. Bologna, Italy: Edagricole.

Brambilla, M., Romano, E., Cutini, M., Bisaglia, C., \& Pari, L. (2013). Rheological properties of manure/biomass mixtures and pumping strategies to improve ingestate formulation: A review. Trans. ASABE, 56(5), 1905-1920.

http://dx.doi.org/10.13031/trans.56.9975.

Chiumenti, A., Da Borso, F., Chiumenti, R., Teri, F., \& Segantin, P. (2013). Treatment of digestate from a co-digestion biogas plant by means of vacuum evaporation: Tests for process optimization and environmental sustainability. Waste Mgmt., 33(6), 13391344. http://dx.doi.org/10.1016/j.wasman.2013.02.023.

CRPA. (2012). Digestato, un utile sottoprodotto del biogas. Centro Ricerche Produzioni Animali. Retrieved from http://www.crpa.it/media/documents/crpa_www/Pubblicazi/con oscer\&competere/_conoscerexcompeter_n4.pdf.

England, T., Holmes, B. J., Schuler, R. T., Silha, R., \& Straub, R. J. (2002). Precision land application of animal manure slurry. ASAE Paper No 021012. St. Joseph, Mich.: ASAE.

Funk, T., \& Robert, M. J. (2003). Variable rate manure spreader: Technology to validate a nutrient management plan. Proc. Illinois Pork Industry Conf. Urbana-Champaign, Ill.: Univ. of Illinois.

Gioelli, F., Balsari, P., Dinuccio, E., \& Airoldi, G. (2014). Band application of slurry in orchards using a prototype spreader with an automatic rate controller. Biosyst. Eng., 121, 130-138. http://dx.doi.org/10.1016/j.biosystemseng.2014.02.012.

Mazzetto, F., Calcante, A., \& Orsi, E. (2012a). Design, development and evaluation of a device for the monitoring of liquid manure distribution using big gun sprinkler distribution system. Appl. Eng. Agric., 27(4), 569-576. http://dx.doi.org/10.13031/2013.38203.

Mazzetto, F., Sacco, P., \& Calcante, A. (2012b). Algorithms for the interpretation of continuous measurement of the slurry level in storage tanks. J. Agr. Eng., 43(1), 36-42. $\mathrm{http} / / / \mathrm{dx}$. doi.org/10.4081/jae.2012.e6.

Minitab 17 Statistical Software. (2010). State College, Pa.: Minitab, Inc. Retrieved from www.minitab.com.

Misselbrook, T. H., Smith, K. A., Johnson, R. A., \& Pain, B. F. (2002). SE-Structures and environment: Slurry application techniques to reduce ammonia emissions: Results of some UK field-scale experiments. Biosyst. Eng., 81(3), 313-321. http://dx.doi.org/10.1006/bioe.2001.0017.

Morris, D. K., Ess, D. R., Hawkins, S. E., \& Parson, S. D. (1999). Development of a site-specific application system for liquid animal manures. Appl. Eng. Agric., 15(6), 633-638. http://dx.doi.org/10.13031/2013.5829.

Munack, A., Speckmann, H., \& Diler, E. (2001). Adaptive predictive control of liquid manure spreading. ASAE Paper No 881057. St. Joseph, Mich: ASAE.

Negri, M., \& Maggiore, T. (2012). Il valore agronomico del digestato. Intersezioni, 22. Retrieved from http://www.intersezioni.eu/public/art_296/22\%20Agronomia $\% 2$ 0TM\%20et\%20al.pdf.

Oh, I. H., Lee, J., \& Burns, R. T. (2004). Development and evaluation of a multi-hose slurry applicator for rice paddy fields. Appl. Eng. Agric., 20(1), 101-106. http://dx.doi.org/10.13031/2013.15688.

Provolo, G., \& Martinez-Suller, L. (2007). In situ determination of slurry nutrient content by electrical conductivity. Bioresource Tech., 98(17), 3235-3242. http://dx.doi.org/10.1016/j.biortech.2006.07.018. 
Ruiz-Ramos, M., Gabriel, J. L., Vazquez, N., \& Quemada, M. (2011). Evaluation of nitrate leaching in a vulnerable zone: Effect of irrigation water and organic manure application. Spanish J. Agric. Res., 9(3), 924-937. http://dx.doi.org/10.5424/sjar/20110903-237-10.

Saeys, W., Deblander, J., Ramon, H., \& Anthonis, J. (2008). Highperformance flow control for site-specific application of liquid manure. Biosyst. Eng., 99(1), 22-34. http://dx.doi.org/10.1016/j.biosystemseng.2007.09.009.

Saeys, W., Mouazen, A. M., \& Ramon, H. (2005). Potential for onsite and online analysis of pig manure using visible and near infrared reflectance spectroscopy,. Biosyst. Eng., 91(4), 393-402. http://dx.doi.org/10.1016/j.biosystemseng.2005.05.001.

Safley, L. M., Barker, J. P., \& Westerman, P. W. (1984). Modification of a slurry manure injector for plot research. Trans. ASAE, 27(2), 348-352. http://dx.doi.org/10.13031/2013.32788.
Schellberg, J., \& Lock, R. (2009). A site-specific slurry application technique on grassland and on arable crops. Bioresource Tech., 100(1), 280-286.

http://dx.doi.org/10.1016/j.biortech.2008.05.044.

Scotford, I. M., Cumby, T. R., \& Inskip, P. F. (2001). AEAutomation and emerging technologies: Improving the control and accuracy of slurry spreaders,. J. Agr. Eng. Res., 79(2), 139149. http://dx.doi.org/10.1006/jaer.2000.0696.

Thygesen, O., Triolo, J. M., \& Sommer, S. G. (2012). Indicators of physical properties and plant nutrient content of animal slurry and separated slurry. Biol. Eng., 5(3), 123-135. http://dx.doi.org/10.13031/2013.4227.

UNI. (2002). UNI-EN 13406:2002 Agricultural machinery -Slurry tankers and spreading devices - Environmental protection Requirements and test methods for the spreading precision. 